\title{
DANTOVO PEKLO JAKO ARCGIS STORYMAP
}

\author{
DANTE'S INFERNO AS AN ARCGIS STORYMAP
}

\author{
Josef Münzberger ${ }^{*}, 1$ \\ *josef.munzberger@fsv.cvut.cz \\ ${ }^{1}$ ČVUT v Praze, Fakulta stavební, Katedra geomatiky
}

\begin{abstract}
Abstrakt
StoryMap vznikla za účelem rekonstrukce polohy a struktury Dantova Inferna. Jednotlivé komponenty (mapy a 3D model) byly sestaveny na základě analýzy Komedie a raných studií věnovaných mapování Pekla (A. Manetti, G. Galilei). Doplněny o vybrané verše a doprovodný text seznamují v rámci StoryMap uživatele s problematikou určení lokace, tvaru a členění Pekla. Literární dílo z počátku 14. století tak za pomoci moderních technologií znovuoživá v interaktivní podobě a lze na něj nahlížet z netradiční perspektivy.
\end{abstract}

\section{Klíčová slova}

Inferno, Dante Alighieri, Antonio Manetti, Galileo Galilei, StoryMap

\begin{abstract}
StoryMap was created to reconstruct the location and structure of Dante's Inferno. Its components (maps and 3D model) were built up based on an analysis of Comedy and early studies devoted to the mapping of Hell (A. Manetti, G. Galilei). Accompanied by selected verses and supporting text, they let the readers follow the story of determining the location, shape, and division of Hell. The literary work dated to the beginning of the 14th century is thus revived thanks to modern technologies and can be viewed from a non-traditional perspective.
\end{abstract}

Key words

Inferno, Dante Alighieri, Antonio Manetti, Galileo Galilei, StoryMap

\section{1 ÚVOD}

V letošním roce uplyne 700 let od dokončení jednoho z největších středověkých literárních děl, Dantovy Komedie [1]. Od svého vydání dodnes dílo italského autora fascinuje laickou i odbornou veřejnost a zejména na poli vědy se stalo předmětem podrobných studií a komentářů. Ačkoliv se jednalo převážně o literární rozbory či filosofické výklady, komedie byla rovněž podrobena řadě matematických a geometrických analýz, které si kladly za cíl určit tvar Pekla a zejména identifikovat jeho polohu na Zemi (resp. pod zemským povrchem). Báseň totiž obsahuje popis vize Dantova putování Peklem, Očistcem a Rájem, který je natolik detailní, že středověkou vědu skutečně přivedl k otázce, zda by bylo možné na základě veršủ Dantova díla Peklo zmapovat.

\section{HISTORICKÝ VÝVOJ}

Historicky první exaktní výpočet provedl florentský matematik Antonio Manetti, který své výsledky představil roku 1506. Z textu básně vyvodil matematické vztahy a výpočty, jejichž pomocí určil tvar, kompletní strukturu a lokaci Inferna. O několik desítek let později (1544) nabídl radikálně odlišný model Alessandro Vellutello, což zapříčinilo vleklý spor ve vědeckých kruzích ohledně korektnosti postupu dvojice badatelů. Debaty ukončil až Galileo Galilei, který obhájil (1588) Manettiho verzi. Galileovy přednášky [2], které byly dlouho považovány za ztracené, se staly společně s vlastní analýzou Komedie stěžejními podklady autorovy diplomové práce.

Proces tvorby komplexní StoryMap Dantovo Inferno lze rozdělit do několika fází, které jsou přiblíženy v následující kapitole. Před samotnou metodikou je na místě uvést definici tvaru Inferna a jeho prostorové identifikace podle Manettiho. Jak jej názorně parafrázoval ve svých přednáškách Galileo: „Představme si spojnici vedouci ze středu Země do Jeruzaléma a dále oblouk, vedoucí z tohoto města po povrchu Země do jedné dvanáctiny jejiho obvodu. Z druhého konce oblouku, než na kterém se nacházi Jeruzalém, spust’me kolmici do středu Země. 
Máme tedy kruhovou výseč, jejiž obvod je roven dvanáctině obvodu Země a která je ohraničena spojnicemi se středem Země. Pokračujme tím, že spojnice středu Zeměs Jeruzalémem zůstává fixní a oblouk s druhou spojnicí necháme kolem ní rotovat, dokud se nedostane do své pưvodni polohy. Takovým pohybem bude vyř́znuta kuželovitá část, po které, pokud bychom ji ze Země vyňali, zůstane prostor, v němž se rozkládá Inferno. "Peklo lze tedy obecně označit za kónickou propast s vrcholem ve středu Země a s ústím nacházejícím se pod zemským povrchem tak, že město Jeruzalém leží přesně nad jeho středem. Citovaný úryvek v tomto odstavci byl volně přeložen dle [2].

Uvnitř pekelného kužele se podle Danta nachází postupně devět kruhů. Ty lze připodobnit k prstencům, které se obtáčí po vnitřní straně pláště na různých výškových úrovních se sestupnou tendencí. Devatero Dantových kruhů vychází z Aristotelovy Etiky, která obsahuje rozdělení hříchů dle závažnosti. Aristotelovské pojetí viny vnímá zradu jako nejhorší hřích, proto se takto provinilí nachází v Pekle nejhlouběji (tj. v devátém kruhu). Každý kruh je tedy spjat s jiným hříchem, dílčí části kruhů pak korespondují se specifickou formou daného hříchu. Např. sedmý kruh, kde se trestá násilí, se dělí na tři pásma: řeka Flegeton (násilí proti bližnímu), Les sebevrahů (násilí proti sobě) a Pláň hořícího písku (násilí proti Bohu, př́rodě).

\section{METODIKA}

\subsection{Tvorba map}

Základ pro StoryMap představují jednoznačně mapy. Vzhledem k problematice bylo stanoveným cílem vytvořit dvě tematické: první (mapu světa, viz Obr. 1), orientovanou na zobrazení promítnutých hranic Pekla na zemský povrch, a druhou (mapu podsvětí, viz Obr. 2), zaměřenou na podrobnou strukturu Inferna. Celé zpracování proběhlo v programu ArcGIS Pro.

Vstupní data zahrnovala opendata (Natural Earth, ArcGIS Living Atlas of the World) a vlastní tabulky sestavené dle analýzy Komedie a parametrů stanovených Manettim. Do samotného středu mapy světa byl po vzoru středověkých mappae mundi umístěn Jeruzalém. Jelikož obrazy základních pekelných hranic tvoří na povrchu Země koncentrické kruhy se středem právě ve svatém městě, bylo zásadní zvolit vhodnou kartografickou projekci zachovávající vzdálenosti od středu. Takové kritérium splňuje modifikované azimutální ekvidistantní zobrazení se zeměpisnými souřadnicemi středu nastavenými na Jeruzalém.

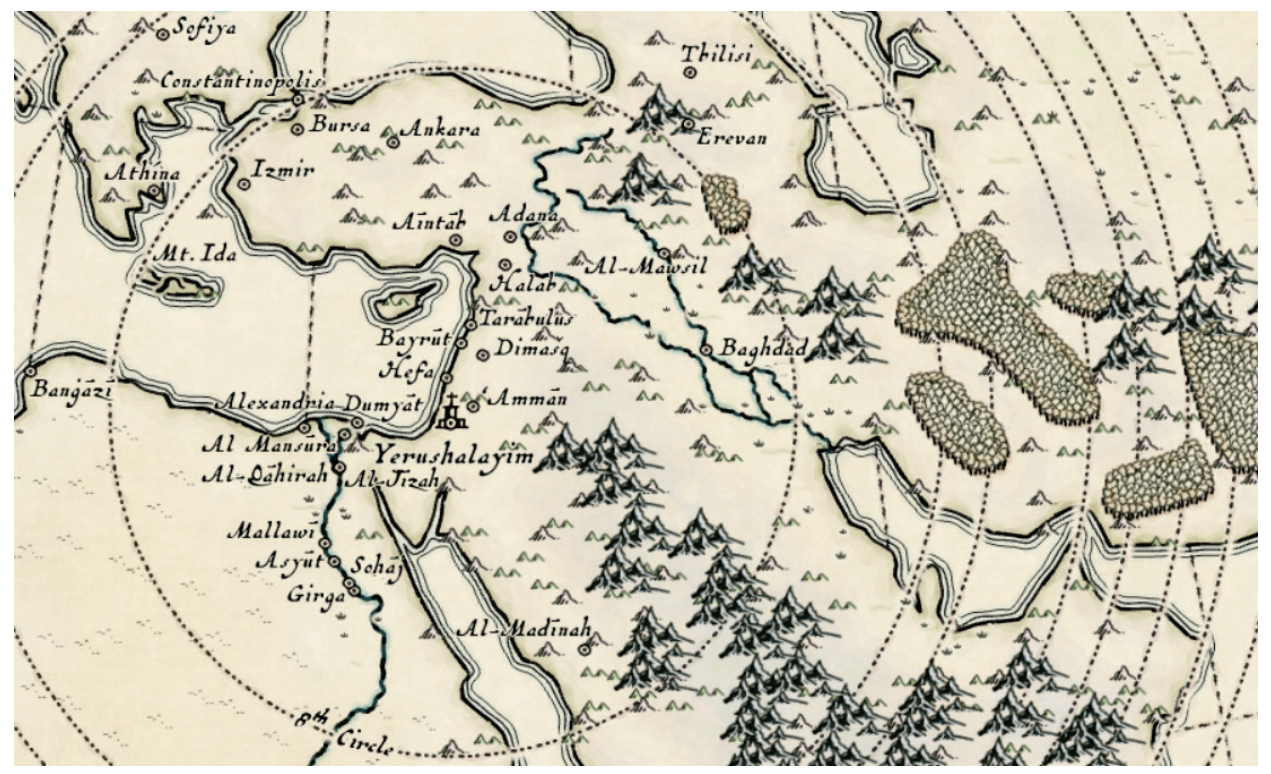

Obr. 1 Ukázka mapy světa.

Na rozdíl od mapy světa, kterou lze bez problémů zaplnit geodaty, v Komedii není pro naplnění mapy podsvětí až na několik výjimek (tři pekelné řeky či Les sebevrahů) dostatek jednoznačných informací o topografických prvcích Inferna. Z tohoto důvodu byla podle básně sestavena databáze postav, které Dante na své pouti potkává. 
Ačkoliv nelze určit přesné souřadnice, na kterých se daná postava v Pekle nachází, lze s jistotou tvrdit, do jaké konkrétní části Pekla byla uvržena. A jelikož Manetti určil též trasu Dantova putování, bylo možné podél její spirálovité linie rozmístit bodové prvky napojené na zmíněnou databázi a reprezentující tak jednotlivé postavy.

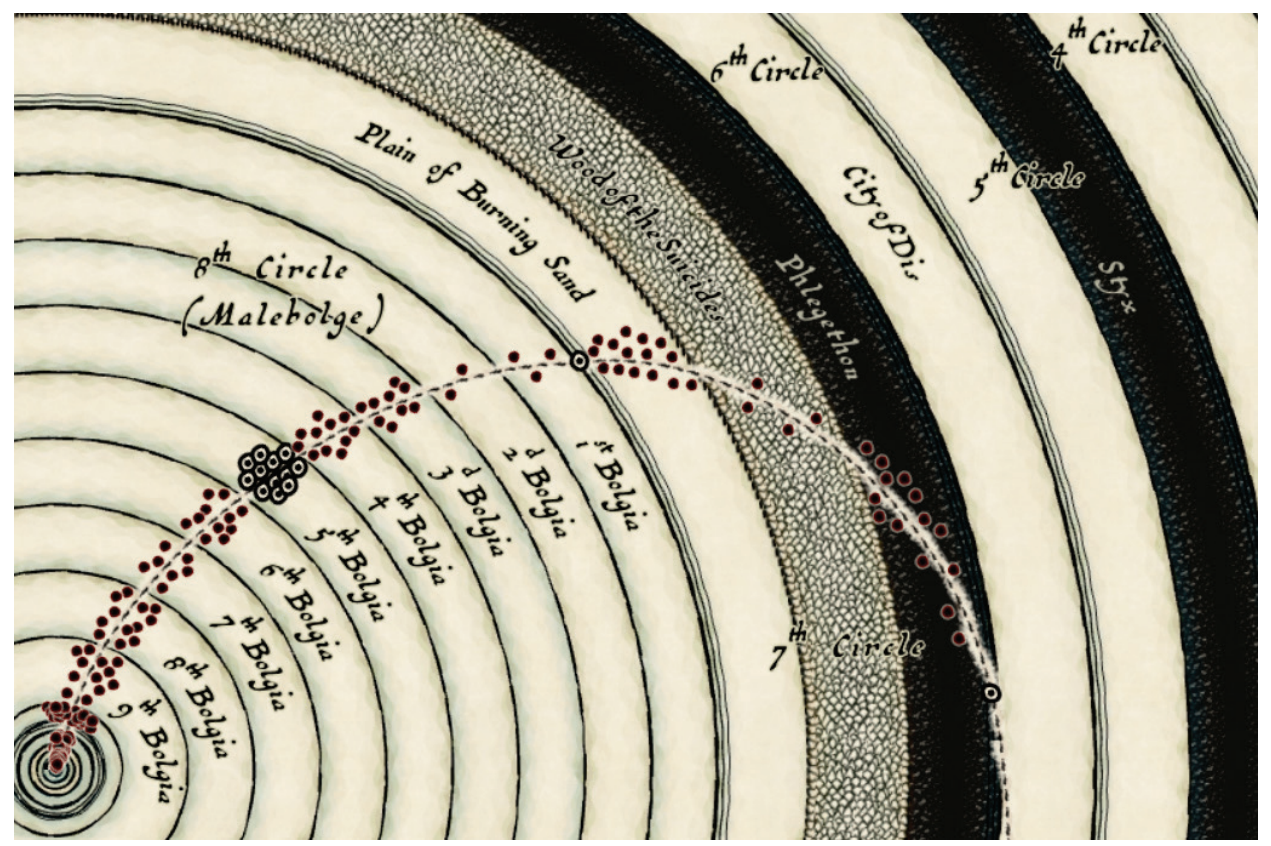

Obr. 2 Výřez mapy podsvětí.

Obsahy obou map byly připraveny pro několik měřítek; s větším detailem roste počet zobrazovaných prvků. Symbologie byla inspirována ArcGIS Pro stylem autora Johna M. Nelsona, který je volně dostupný v online galerii stylů Esri pod názvem My Precious a vychází ze stylizace map J. R. R. Tolkiena [3]. Symbologie byla doplněna fontem z produkce Three Islands Press (lze zakoupit nap̌r. na https://www.oldfonts.com/terra-ignota.html), jenž byl navržen dle mapy Amerique Septentrionale (1650) francouzského kartografa Nicolase Sansona. Výsledná kombinace použitého stylu, fontu či např. umístění Jeruzaléma v centru mapy tak podtrhává odkaz celku na středověká kartografická díla.

\subsection{Upload na AGOL}

Po dokončení obou map následoval upload z ArcGIS Pro do prostředí ArcGIS Online. Kartografické zobrazení se na AGOL řídí projekcí podkladové mapy, a proto byly ještě před samotným transferem připraveny pro každou z map dvě složky: basemap a sada vektorových vrstev, ke které byla později navázána funkcionalita (např. popups). Proces prípravy podkladových map zahrnoval nejprve tvorbu dlaždicového schématu za pomoci nástroje Generate Map Server Cache Tiling Scheme, v němž byla pro každou mapu nastavena konkrétní měřítková řada a velikost dlaždic. Při samotné publikaci přes funkci Share as a Web Layer byly jako typ publikované vrstvy nastaveny rastrové dlaždice (tile) a zvoleno vytvořené XML schéma v předchozím kroku. Sada vektorových vrstev každé mapy obsahující zejména bodové a liniové prvky byla publikována standardním způsobem.

Jakmile byly obě složky mapy světa i podsvětí převedeny do cloudového prostředí AGOL, bylo přistoupeno ke skladbě finálních map. Pro vybrané vektorové vrstvy byly nastaveny vyskakovací okna, do nichž byly zakomponovány dodatečné informace $\mathrm{z}$ atributové tabulky a věkterých případech i zobrazena související ilustrace (viz obr. 3, 4).

Mezi konkrétní údaje zařazené z atributové tabulky do vyskakovacích oken pekelných sekcí patří jejich šíře, výška nad středem Země, šířka jejich obrazu na povrchu, číslo zpěvu, v němž jsou v básni zmíněny, krátký popis, trestaný hřích a číslo nadřazeného kruhu. Pop-up postavy tvoří popisek, údaj o sekci Pekla, v níž se nachází, a př́padně atribut kategorie, pokud byla daná postava reprezentantem skupiny s početnějším zastoupením (př́kladem kategorie mohou být církevní hodnostáři, kterých Dante do Pekla umístil hned několik). 


\subsection{Mapa s příběhem}

Teorii tvorby mapy s př́během se věnuje specifický proud problematiky narativních struktur, jehož rešerší se zabývala první část autorovy diplomové práce [4]. Zásadním pramenem $\mathrm{v}$ tomto ohledu byla publikace A Conceptual Framework For Interactive Cartographic Storytelling [5]. Na jejím základě společně se zmíněnou rešerší byly selektovány principy a postupy, které byly dále uplatněny při návrhu výsledné StoryMap.

Dle Rothovy taxonomie žánrů kartografického storytellingu [6] spadá vytvořené dílo do třídy Multimedia Visual Experience. Schéma obsahu odpovídá spíše autorem řízenému př́istupu (author-driven), který je založen na př́mé distribuci informací čtenáři na rozdíl od nutnosti interakce. Ta je sice možná, ale představuje pouhou nadstavbu a lze ji zcela vynechat. Konkrétněji lze dle klasifikace [7] výsledné obsahové schéma nejlépe přirovnat k modifikaci (resp. sérii) Martini Glass. Jakmile je obsah završen (čili je obrazně rozlita sklenice Martini), dochází ke změně př́istupu (z author-driven na reader-driven) a čtenáři je umožněno interagovat s odhalenými daty.

\section{VÝSLEDKY}

Tato kapitola obsahuje galerii ukázek z finální podoby StoryMap Dantovo Inferno, nicméně pro komplexní dojem lze zhlédnout dílo přes odkaz: https:/storymaps.arcgis.com/stories/f978388543a74088991be9492258614c.

\begin{tabular}{|l|l|}
\hline Řeka Styx & 5 \\
\hline Číslo kruhu & hněv \\
\hline Hřích & $\begin{array}{l}\text { Pátý kruh (kruh zloby) je z první } \\
\text { poloviny tvořen řekou Styx. V } \\
\text { jejích bahnitých vodách spolu } \\
\text { zápasí duše hněvivých. Přes řeku } \\
\text { básníci využijí služeb jiného } \\
\text { převozníka - Flegia. }\end{array}$ \\
\hline Zpěv & VIII \\
\hline Šir̃e [km] & 61,946 \\
\hline Šiŕka na povrchu [km] & 165,189 \\
\hline Výška nad středem Země [km] & 2010,425 \\
\hline Anglický název & Styx \\
\hline
\end{tabular}

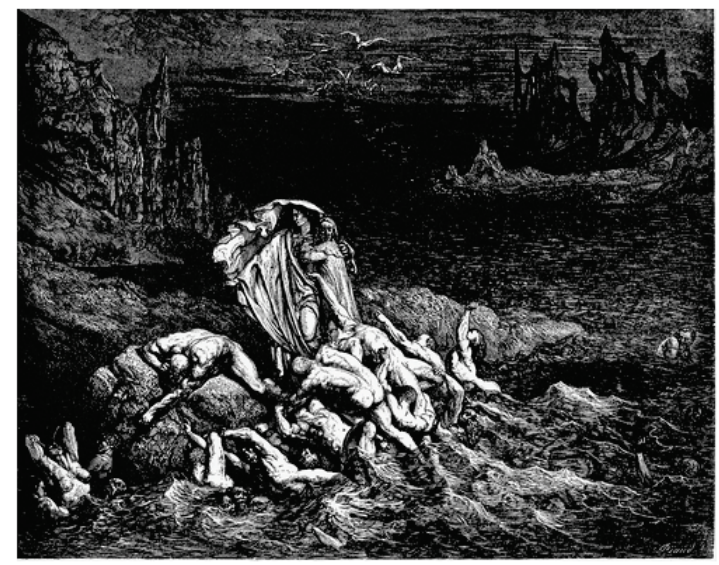

Obr. 3 Vyskakovací okno jedné z pekelných sekcí. 


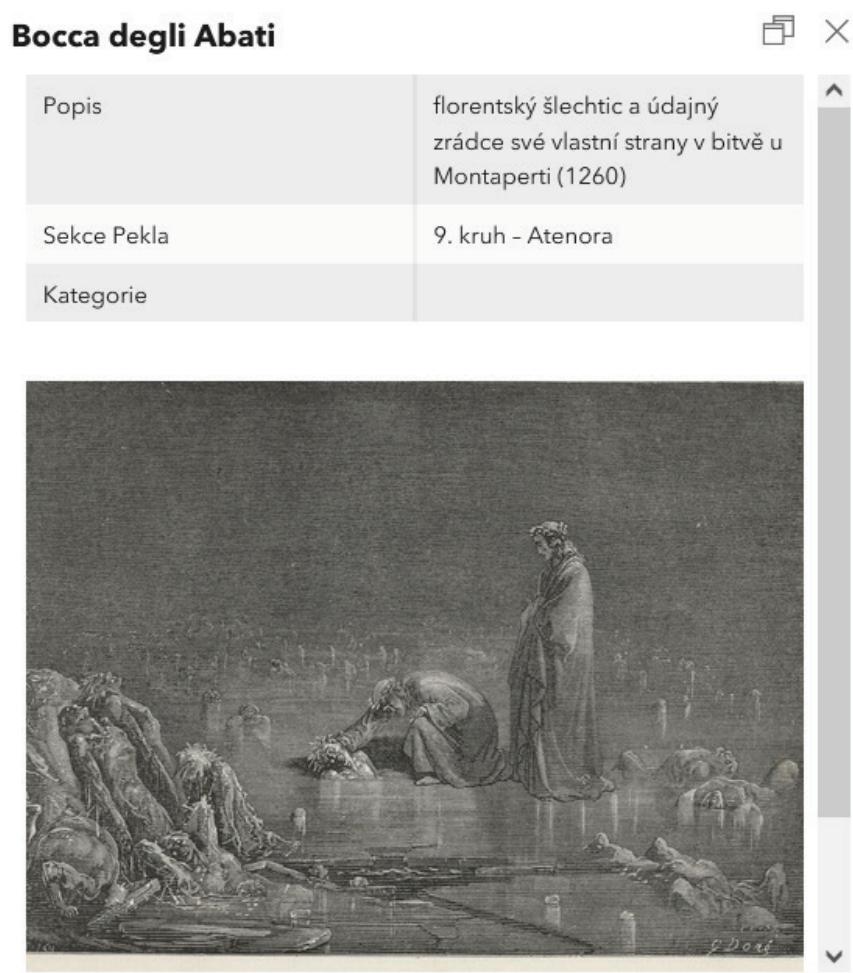

Obr. 4 Vyskakovací okno jednoho z hř́šníků.

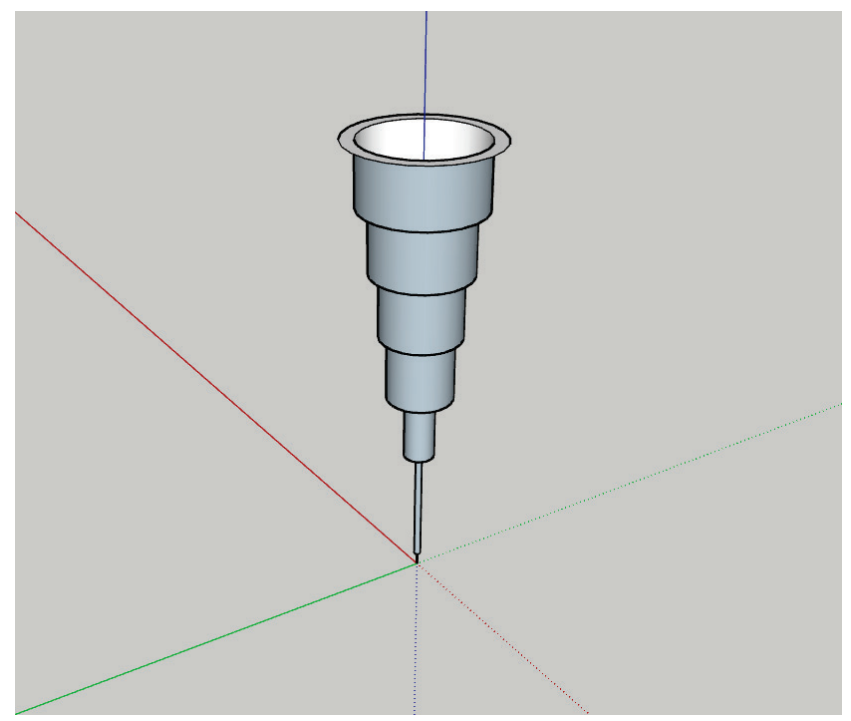

Obr. 5 Celkový pohled na kužel Inferna (SketchUp). 


\section{DISKUZE}

StoryMap byla koncipována způsobem, jímž uživatele postupným přibližováním ke středu Země seznamuje s kontextem literárního konceptu Inferna. Nejprve nahlíží na významné body na zemském povrchu, od nichž byla poloha Pekla odvozena, společně s obrazy základních hranic Pekla. Ve větším detailu odhaluje mnohá významná středověká města. V další fázi již čtenáře přenese pod povrch Země a v několika úrovních detailu nabízí podrobnou strukturu Inferna včetně připojené databáze hříšníků a démonů, čímž plní roli interaktivní encyklopedie všech postav Komedie. V rámci mapových oken uživatele provází postranní panel s textem, který byl připraven pro jednotlivé úrovně detailu. Skládá se vždy z významného úryvku veršủ Komedie, jenž sloužil k Manettiho výpočtům, a komentáře, jímž vysvětluje aktuální zobrazení na mapě či souvislosti s citovaným veršem.

Celý př́běh uzavírá virtuální prohlídka 3D modelem Inferna, který byl sestaven v software SketchUp podle Manettiho parametrů (viz Obr. 5). 3D vizualizace dodává struktuře Pekla nový rozměr a ukazuje tak čtenáři specifika, které nebylo možné dostatečně vyjádřit samotnou mapou.

\section{ZÁVĚR}

V rámci diplomové práce bylo znovuoživeno středověké téma mapování Pekla. Byly provedeny analýzy za pomoci moderních technologií a prezentovány výstupy populárně-naučnou formou v mapě s př́během - StoryMap. Takto komplexně nebylo z pohledu geografie Dantovo Inferno doposud prozkoumáno. V současnosti, kdy se technologie sběru prostorových dat vyvíjejí závratnou rychlostí, představuje aplikovaná metodika jakýsi protipól k aktuálním trendům, návrat do minulosti. Zisk a interpretace geodat obsažených v sedm staletí starém literárním díle spíše než nenásledování pokroku dokládá interdisciplinární překračování hranic a unikátně zvolený přistup.

Ačkoliv se z dnešního pohledu může zdát problematika mapování Inferna bizarní, je nutné si ještě uvědomit, jakým způsobem bylo formováno středověké vnímání světa. Na něj totiž měla zásadní vliv církev, tudíž např. existence Pekla byla brána dogmaticky. V neposlední řadě tak výsledná StoryMap může být zajímavou sondou do středověkých představ o fungování světa nebo též dokladem Dantovy autority překračující hranice literatury.

\section{Použité zdroje}

[1] ALIGHIERI, Dante. Božská komedie. Přeložil Otto František Babler. Praha: Nakladatelství Vyšehrad, 1952. ISBN 978-80-7390-041-0.

[2] GALILEI, Galileo. Due Lezioni All'accademia Fiorentina: Circa La Figura, Sito E Grandezza Dell'inferno Di Dante [online]. Do angličtiny přeložil Mark A. Peterson. Dostupné z: https://www.mtholyoke.edu/courses/mpeterso/galileo/inferno.html.

[3] NELSON, John. Mapping With Style, Vol. 1 [online]. Esri, 2018 [cit. 2021-11-02].

[4] MÜNZBERGER, Josef. Dantovo Peklo jako ArcGIS StoryMap. Praha, 2021. Dostupné z: https://dspace.cvut.cz/handle/10467/95903. Diplomová práce. ČVUT. Vedoucí práce Prof. Ing. Jiří Cajthaml, Ph.D.

[5] LANDAVERDE CORTÉS, Noé Abraham. A Conceptual Framework For Interactive Cartographic Storytelling [online]. Enschede, 2018 [cit. 2021-3-16]. Dostupné z: http://essay.utwente.nl/85868/. Master's essay. University of Twente.

[6] ROTH, Robert E. Cartographic Design as Visual Storytelling: Synthesis and Review of Map-Based Narratives, Genres, and Tropes. The Cartographic Journal [online]. 2020 [cit. 2021-12-10]. ISSN 1743-2774. DOI: 10.1080/00087041.2019.1633103

[7] SEGEL, Edward a Jeffrey HEER. Narrative Visualization: Telling Stories with Data. IEEE Transactions on Visualization and Computer Graphics [online]. 2011 [cit. 2021-12-10]. ISSN 1941-0506. DOI: 10.1109/TVCG.2010.179 